\title{
Heavy Metals in Barnacles Balanus sp.: From Biomonitoring to Coastal Management
}

\author{
Chee Kong Yap ${ }^{1 *}$, Wing Sam Lo ${ }^{1}$, Rosimah Nulit ${ }^{1}$, Mohd Hafiz Ibrahim ${ }^{1}$, Chee Wah Yap ${ }^{2}$, Moslem \\ Sharifinia ${ }^{3}$, Alireza Riyahi Bakhtiari ${ }^{4}$ and Salman Abdo Al Shami ${ }^{5}$ \\ ${ }^{1}$ Department of Biology, Faculty of Science, University Putra Malaysia, Malaysia
}

${ }^{2}$ Mes Solutions, Selangor, Malaysia

${ }^{3}$ Department of Agricultural, Iranian Fisheries Science Research Institute, Education and Extension Organization (AREEO), Iran

${ }^{4}$ Department of Environmental Sciences, Faculty of Natural Resources and Marine Sciences, Tarbiat Modares University, Iran

${ }^{5}$ Indian River Research and Education Center, IFAS, University of Florida, USA

*Corresponding author: Chee Kong Yap, Department of Biology, Faculty of Science, University Putra Malaysia, 43400 UPM, Serdang, Selangor, Malaysia.

To Cite This Article: Chee Kong Yap, Heavy Metals in Barnacles Balanus sp.: From Biomonitoring to Coastal Management. Am J Biomed Sci \& Res. 2020 - 7(2). AJBSR.MS.ID.001128. DOI: 10.34297/AJBSR.2020.07.001128.

Received: 鴜 January 29, 2020; Published: 㘹 February 04, 2020

\begin{abstract}
This study determined the levels of $\mathrm{Cd}, \mathrm{Cu}, \mathrm{Fe}, \mathrm{Ni}$, and $\mathrm{Zn}$ in the soft tissues and shells of barnacles (Balanus sp.) collected from the Kuala Juru, Sebatu, Sg. Ayam and Kg. Pasir Puteh, Peninsular Malaysia, obtained in 2008. The metal concentrations ( $\mu$ g/g dry weight) in the soft tissues of Balanus sp. received from four sites in Peninsular Malaysia ranged from 2.93-4.17 for Cd, 20.2-92.5 for Cu, 480-1193 for Fe, 6.40-18.0 for Ni, and 224-414 for Zn. Based on the present data, the trace metal bioavailability's to the Balanus in all the populations, especially in a known polluted site at Kg. Pasir Puteh is low. Overall, this preliminary baseline data can be used for regular ecological monitoring for the effective management of the coastal area in Malaysia.
\end{abstract}

Keywords: Barnacles; Heavy metals; Coastal waters of peninsular Malaysia

\section{Introduction}

The first preliminary study on the heavy metal concentrations in the soft tissue and shells of Balanus sp. (Subphylum: Crustacea; Class: Cirripedia) from Malaysia was reported by Yap et al. [1]. As part of regular monitoring of heavy metal contamination and bioavailability's in the coastal waters of Peninsular Malaysia, the data of this study should serve as biomonitoring data for longterm reference in the future. Barnacles have been used to assess the bioavailability of heavy metals in the coastal waters in many countries including India [2, 3], Mexico, Hong Kong [4, 5], China [6] and Poland [7]. According to [8], barnacles are among crustaceans which appear most able to fulfil the characteristics of ideal bio monitors. The objective of this study is to determine the levels of heavy metals in the soft tissues and shells of Balanus sp. collected from four sites in Peninsular Malaysia.

\section{Materials and Methods}

Samples of barnacles Balanus sp. and their habitat surface sediments were collected at the same time in 2008. Sampling locations and site descriptions are shown in Figure 1 \& Table 1, respectively. The collected samples were placed in polyethene bags and stored in the low temperature cold iceboxes and taking back to the laboratory. In the laboratory, the samples were stored at $-10^{\circ} \mathrm{C}$. The measurements of length-width-height of the biological specimens were recorded by using a Vernier caliper to an accuracy of $0.01 \mathrm{~cm}$. The identification of the barnacles was based on the book authored by [9] and George (1979). For metal analysis, the Balanus samples were thawed at room temperature on a clean tissue paper to defrost. After cleaning, the soft tissues of the barnacles were dissected from the hard tissues. They were dried 
in $60^{\circ} \mathrm{C}$ for 72 hours in an oven until constant dry weights. Dried samples were weighed for $0.5 \mathrm{~g}$ and triplicates were analyzed for each pooled sample. They were digested with $10 \mathrm{ml}$ concentrated $\mathrm{HNO}_{3}$ (Analar grade. BDH 69\%) in a hot-block digester first at low temperature $\left(40^{\circ} \mathrm{C}\right)$ for 1 hour and were completely digested at a high temperature $\left(140^{\circ} \mathrm{C}\right)$ for 3 hours [10]. The digested samples were diluted up to $40 \mathrm{ml}$ with DDW and filtered with Whatman filtered paper No. 1 into acid-washed polyethene bottles.

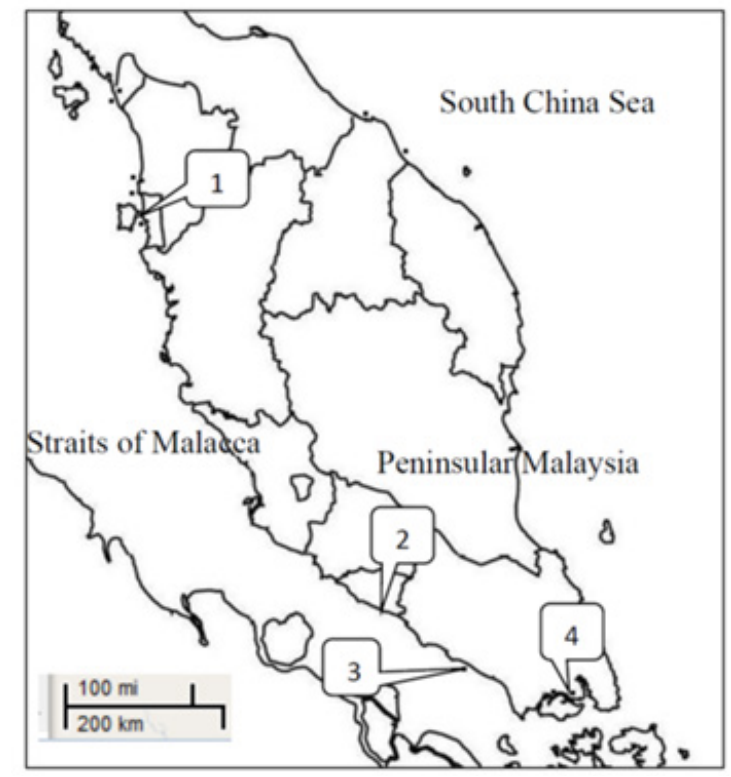

Figure 1: Map showing the sampling sites for barnacles in the west coast of Peninsular Malaysia (1 = Kuala Juru; $2=$ Sebatu; $3=\mathrm{Sg}$. Ayam; $4=$ Kg. Pasir Puteh).

\begin{tabular}{|c|c|c|c|c|c|}
\hline \multicolumn{6}{|c|}{ Table 1: Global Positioning System (GPS), date of sampling and description of all sampling sites for Balanus sp. } \\
\hline No. & Site & S.D. & L-N & L-E & Description \\
\hline 1 & Kuala Juru, Penang & 10-May-08 & $04^{\circ} 59^{\prime}$ & $100^{\circ} 23^{\prime}$ & Mudflats and bird sanctuary \\
\hline 2 & Sebatu, Malacca & 4-May-08 & $02^{\circ} 07^{\prime}$ & $102^{\circ} 37^{\prime}$ & Aqua cultural and agricultural areas \\
\hline 3 & Sg. Ayam, Johore & 2-May-08 & $01^{\circ} 45^{\prime}$ & $102^{\circ} 55^{\prime}$ & Urban area \\
\hline 4 & Kg. Pasir Puteh & 3-May-08 & $01^{\circ} 26^{\prime}$ & $103^{\circ} 56^{\prime}$ & Industrial and port and urban areas \\
\hline
\end{tabular}

Note: L-E=Longitude-East; L-N=Latitude-North; S. D=Sampling Date.

The collected surface sediments were oven-dried and were sieved using $63 \mu \mathrm{m}$ mesh size. For the surface sediment samples, the geochemical fractions of easily, freely, Exchangeable or Leachable (EFLE), acid-reducible (AR), Oxidizable-Organic (O0) and Resistant (Res) were fractionated by sequential extraction technique as suggested by [11]. The concentrations of $\mathrm{Cd}, \mathrm{Cu}, \mathrm{Fe}, \mathrm{Ni}$ and $\mathrm{Zn}$ were determined by an air-acetylene flame Atomic Absorption Spectrophotometer (AAS) Perkin-Elmer Model Analyst 800. The data were presented in $\mu \mathrm{g} / \mathrm{g}$ dry weight. Multiple-level calibration standards were analyzed to generate calibration curves against which sample concentrations were calculated. Standard solutions for each metal were prepared from $1000 \mathrm{mg} / \mathrm{L}$ per stock solution of each metal (MERCK Titrisol).
For quality control, all the glassware and equipment used were acid-washed with $10 \%$ diluted nitric acid solution for one night long. Procedural blanks were prepared for every digestion made for standardization. Quality control samples made from standard solution for $\mathrm{Cd}, \mathrm{Cu}, \mathrm{Fe}, \mathrm{Ni}$ and $\mathrm{Zn}$ were analyzed after five to ten samples to check for accuracy of the samples. The recoveries percentages were acceptable at $80-110 \%$ for each of the heavy metal analyses. The blank samples were subtracted from the results to avoid the contamination possibility. The analytical procedures for the samples were checked with the Certified Reference Material (CRM) for dogfish liver (DOLT-3, National Research Council Canada) (Table 2).

Table 2: Analytical results for the certified reference material (DOLT-3 Dogfish liver) and the measured values for each metal ( $\mu$ g/g dry weight).

\begin{tabular}{|c|c|c|c|}
\hline Metals & Certified Reference Material (CRM) & Measured value & Percentage of recovery (\%) \\
\hline $\mathrm{Cd}$ & 19.7 & 19.4 & 101.7 \\
\hline $\mathrm{Cu}$ & 32.3 & 31.2 & 103.6 \\
\hline
\end{tabular}




\begin{tabular}{|c|c|c|c|}
\hline $\mathrm{Fe}$ & 1322 & 1484 & 89.1 \\
\hline $\mathrm{Ni}$ & 3.95 & 2.72 & 145 \\
\hline $\mathrm{Zn}$ & 86.7 & 86.6 & 100.2 \\
\hline
\end{tabular}

\section{Results and Discussion}

Table 3 shows the allometric data for all populations of Balanus sp. from the four sampling sites in Peninsular Malaysia. The levels of $\mathrm{Cd}, \mathrm{Cu}, \mathrm{Fe}, \mathrm{Ni}$ and $\mathrm{Zn}$ in the soft tissues and shells of Balanus sp. collected from the four sites are presented in Table 4. Table 5 shows the levels of the five heavy metals in the four geochemical fractions of surface sediments collected from the four sampling sites. For
Cd levels in the shells: Sg. Ayam> Sebatu> Kuala Juru > Kg. Pasir Puteh. For Cd levels in the soft tissues: Sg. Ayam> Kg. Pasir Puteh> Sebatu> Kuala Juru. This highest bioavailable Cd levels to the Balanus collected from Sg. Ayam is well supported by the highest contamination level of $\mathrm{Cd}$ in the surface sediments represented by the geochemical fractions of EFLE and AR, and the highest percentage of non-resistant faction (59.3\%) (Table 5).

\begin{tabular}{|c|c|c|c|c|}
\hline Parameters & Sg. Ayam & Sg. Sebatu & Kuala Juru & Kg. Pasir Puteh \\
\hline \multirow{2}{*}{ Length $(\mathrm{cm})$} & $2.50 \pm 0.18$ & $2.02 \pm 0.12$ & $0.60 \pm 0.01$ & $1.00 \pm 0.04$ \\
\hline & $(1.75-3.46)$ & $(1.50-2.52)$ & $(0.55-0.70)$ & $(0.73-1.17)$ \\
\hline \multirow{2}{*}{ Width $(\mathrm{cm})$} & $2.24 \pm 0.13$ & $2.34 \pm 0.15$ & $0.64 \pm 0.01$ & $1.09 \pm 0.05$ \\
\hline & $(1.52-2.85)$ & $(1.70-2.93)$ & $(0.61-0.71)$ & $(0.87-1.39)$ \\
\hline \multirow{2}{*}{ Height $(\mathrm{cm})$} & $2.36 \pm 0.23$ & $2.20 \pm 0.16$ & $0.53 \pm 0.01$ & $0.86 \pm 0.08$ \\
\hline & $(1.23-3.28)$ & $(1.38-3.05)$ & $(0.48-0.59)$ & $(0.55-1.35)$ \\
\hline \multirow{2}{*}{ Full Body Wet (g) } & $8.51 \pm 1.31$ & $5.52 \pm 0.96$ & NA & NA \\
\hline & $(1.82-14.4)$ & $(2.08-11.2)$ & & \\
\hline \multirow{2}{*}{ Full Body Dry (g) } & $5.33 \pm 0.86$ & $4.19 \pm 0.76$ & NA & NA \\
\hline & (0.91-8.99) & $(1.62-9.24)$ & & \\
\hline \multirow{2}{*}{ Water Content (g) } & $38.8 \pm 1.59$ & $23.3 \pm 3.44$ & NA & NA \\
\hline & $(32.9-50.0)$ & $(7.27-42.7)$ & & \\
\hline
\end{tabular}

Note: Data not available; values in brackets in minimum to maximum.

\begin{tabular}{|c|c|c|c|c|c|c|}
\hline Site & Part & Cd & $\mathrm{Cu}$ & $\mathrm{Fe}$ & $\mathbf{N i}$ & $\mathbf{Z n}$ \\
\hline \multirow{4}{*}{ Sg. Ayam } & Shell & $4.34 \pm 0.05$ & $7.72 \pm 0.09$ & $1190 \pm 31.9$ & $33.1 \pm 0.70$ & $29.2 \pm 2.32$ \\
\hline & & B & $\mathrm{A}$ & $\mathrm{A}$ & B & A \\
\hline & ST & $4.17 \pm 0.01$ & $37.2 \pm 1.23$ & $1193 \pm 36.9$ & $6.40 \pm 0.11$ & $256 \pm 5.02$ \\
\hline & & $\mathrm{A}$ & B & A & A & B \\
\hline \multirow{4}{*}{ Kg. Pasir Puteh } & Shell & $0.70 \pm 0.04$ & $7.32 \pm 0.20$ & $418 \pm 7.61$ & $25.9 \pm 0.49$ & $41.8 \pm 1.15$ \\
\hline & & B & A & A & B & A \\
\hline & ST & $3.46 \pm 0.07$ & $49.5 \pm 0.00$ & $717 \pm 0.00$ & $8.57 \pm 0.00$ & $414 \pm 0.00$ \\
\hline & & A & B & B & A & B \\
\hline \multirow{4}{*}{ Sg. Sebatu } & Shell & $4.26 \pm 0.09$ & $5.44 \pm 0.05$ & $466 \pm 12.8$ & $25.6 \pm 0.65$ & $20.9 \pm 0.29$ \\
\hline & & A & $\mathrm{A}$ & A & B & A \\
\hline & ST & $3.01 \pm 0.68$ & $20.2 \pm 0.18$ & $1179 \pm 8.11$ & $9.24 \pm 0.59$ & $385 \pm 6.76$ \\
\hline & & B & B & B & A & B \\
\hline \multirow{4}{*}{ Kuala Juru } & Shell & $3.82 \pm 0.11$ & $11.8 \pm 0.52$ & $144 \pm 4.71$ & $24.6 \pm 0.84$ & $20.5 \pm 0.39$ \\
\hline & & B & $\mathrm{A}$ & A & B & A \\
\hline & ST & $2.93 \pm 0.05$ & $92.5 \pm 5.66$ & $480 \pm 14.1$ & $18.0 \pm 0.72$ & $224 \pm 3.67$ \\
\hline & & A & B & B & A & B \\
\hline
\end{tabular}

Note: Metal concentration of different parts sharing a common letter in the post hoc column is not significantly different $(P>0.05)$. 


\begin{tabular}{|c|c|c|c|c|c|c|}
\hline & & Cd & $\mathrm{Cu}$ & $\mathrm{Fe}$ & $\mathbf{N i}$ & Zn \\
\hline \multirow{4}{*}{ EFLE } & KSAyam & 0.31 & 0.17 & 48.56 & 0.63 & 0.9 \\
\hline & KPPuteh & 0.22 & 0.41 & 154.3 & 0.61 & 2.86 \\
\hline & Sebatu & 0.1 & 0.31 & 99.95 & 0.1 & 0.97 \\
\hline & Kjuru & 0.1 & 1.3 & 0.42 & 0.74 & 2.85 \\
\hline \multirow{4}{*}{$\mathrm{AR}$} & KSAyam & 0.67 & 0.33 & 34.09 & 1.35 & 0.74 \\
\hline & KPPuteh & 0.07 & 0.28 & 373.3 & 0.25 & 6.78 \\
\hline & Sebatu & 0.26 & 0.45 & 79.84 & 0.67 & 2.8 \\
\hline & Kjuru & 0.07 & 0.55 & 568.5 & 1.88 & 32.98 \\
\hline \multirow{4}{*}{00} & KSAyam & 0.17 & 3.96 & 4184.56 & 8.14 & 45.3 \\
\hline & KPPuteh & 0.3 & 8.34 & 23141 & 16.93 & 39.54 \\
\hline & Sebatu & 0.07 & 9.01 & 7947 & 8.34 & 45.42 \\
\hline & Kjuru & 0.18 & 17.19 & 2035 & 6.68 & 44.17 \\
\hline \multirow{4}{*}{ Res } & KSAyam & 0.79 & 20.35 & 22467.32 & 12.92 & 83.08 \\
\hline & KPPuteh & 0.68 & 22.98 & 14765 & 9.05 & 42.85 \\
\hline & Sebatu & 0.61 & 27.56 & 19915 & 11.55 & 74.28 \\
\hline & Kjuru & 0.54 & 20.45 & 15236 & 8.67 & 54.25 \\
\hline \multirow{4}{*}{ SUM } & KSAyam & 1.93 & 24.82 & 26734.53 & 23.03 & 130 \\
\hline & KPPuteh & 1.28 & 32.02 & 38433 & 28.8 & 92 \\
\hline & Sebatu & 1.12 & 37.48 & 28042 & 20.66 & 123.4 \\
\hline & Kjuru & 0.89 & 39.48 & 17840 & 17.95 & 134.2 \\
\hline \multirow{4}{*}{ NonR (\%) } & KSAyam & 59.28 & 17.98 & 15.96 & 43.92 & 36.1 \\
\hline & KPPuteh & 46.46 & 28.21 & 61.58 & 66.28 & 53.43 \\
\hline & Sebatu & 41.35 & 26.17 & 28.98 & 44.09 & 39.84 \\
\hline & Kjuru & 39.33 & 48.21 & 14.6 & 51.75 & 59.59 \\
\hline \multirow{4}{*}{$\operatorname{Res}(\%)$} & KSAyam & 40.72 & 82.02 & 84.04 & 56.08 & 63.9 \\
\hline & KPPuteh & 53.54 & 71.79 & 38.42 & 33.72 & 46.57 \\
\hline & Sebatu & 58.65 & 73.83 & 71.02 & 55.91 & 60.16 \\
\hline & Kjuru & 60.67 & 51.79 & 85.4 & 48.25 & 40.41 \\
\hline
\end{tabular}

Note: SUM= summation of EFLE, AR, OO and Res fractions. NonR= Non-resistant fraction consists of EFLE, AR and OO fractions.

For Fe in the shells and soft tissues: Sg. Ayam> Sg. Sebatu> Kg. Pasir Puteh> Kuala Juru. However, these Fe bioavailability results do not agree with the Fe levels in the geochemical fractions in the surface sediments from Sg. Ayam (Table 5) due to Fe is not an anthropogenic metal and complications of other factors affecting the Fe accumulation in the Balanus and physicochemical factors being involved in the sedimentation processes. For $\mathrm{Cu}$, the highest $\mathrm{Cu}$ level was found in the Balanus soft tissues collected from Kuala Juru, followed by Kg. Pasir Puteh, Sebatu and Sg. Ayam. The highest $\mathrm{Cu}$ level in the shells was also found in the Balanus from Kuala Juru. These Balanus results are well supported by the $\mathrm{Cu}$ levels in the surface sediments from Kuala Juru in the geochemical fractions of EFLE, AR and 00, with the highest non-resistant fraction (48.2\%) (Table 5). This indicated the high bioavailable of $\mathrm{Cu}$ to the Balanus collected from Kuala Juru, which is a $\mathrm{Cu}$ contaminated site as evidenced in the surface sediment results.
Inconsistent results are found for Ni levels between soft tissues and shells of Balanus. For Ni the shells: Sg. Ayam> Kg. Pasir Puteh> Sg. Sebatu> Kuala Juru. The reverse pattern was found for the Ni in the soft tissues: Kuala Juru> Sebatu> Kg. Pasir Puteh> Sg. Ayam. Only Balanus soft tissues in the Kuala Juru is supported by the highest Ni levels in the EFLE and AR geochemical fractions (Table 5). For Zn levels in the shells: Kg. Pasir Puteh>Sg. Ayam> Kuala Juru> Sebatu. For Zn levels in the soft tissues: Kg. Pasir Puteh $>$ Sebatu > Sg. Ayam> Kuala Juru. The highest $\mathrm{Zn}$ levels in both shells and soft tissues are supported by EFLE fraction in the surface sediments (Table 5). Although Balanus sp. is not a direct food source to the human, they are feeding source for birds and ducks which become a potential food chain to the end consumers- human. They are potential bio monitor of heavy metal pollution the surrounding environment $[7,8,12,13]$ because they provide integrated measures of the metals supply available to them in the local environment, accumulating 
the metal taken up from food [12]. According to [13,14] $\mathrm{Cu}$ is accumulated by barnacles in $\mathrm{Cu}$ - and sulphur-rich deposits, probably representing end products of the lysosomal breakdown of Cu-containing metallothionein's.

The metal concentrations ( $\mu \mathrm{g} / \mathrm{g}$ dry weight) in the soft tissues of Balanus sp. collected from four sites in Peninsular Malaysia ranged from 2.93-4.17 for $\mathrm{Cd}, 20.2-92.5$ for $\mathrm{Cu}, 480-1193$ for $\mathrm{Fe}$, 6.40-18.0 for $\mathrm{Ni}$, and 224-414 for $\mathrm{Zn}$ (Table 4). The present results are comparable to and lower than those in the Balanus Amphitrite for Hong Kong coastal waters reported by [5] (Cd: 0.69-9.45; Cu: 52.4-1810; Fe: 313-1470; Ni: 1.25-98.9; Zn: 2860-23300). Our results are also comparable to and within those in Balanus sp. collected from Penang's Bridge and Semilang (Peninsular Malaysia) reported by [1, 15-19] (Cd: 4.72-6.66; Cu: 10.3-20.3; Fe: 633-670; Ni: 21.6-23.2; Zn: 361-434).

\section{Conclusion}

This preliminary study on heavy metal levels provides a new baseline against which future local changes can be assessed. This is highly recommended that further studies should be focused on the genetic structures and taxonomy on this potential Balanus sp. that can be established as a good bio monitor in Malaysian coastal waters in the future. Overall, this preliminary baseline data can be used for regular ecological monitoring for the effective management of the coastal area in Malaysia.

\section{Acknowledgement}

The authors wish to acknowledge the financial support provided through the Research University Grant Scheme (RUGS), [Vote no: 91229], by University Putra Malaysia and through e-Science Fund [Vote no: 5450338], by the Ministry of Science, Technology and Innovation, Malaysia.

\section{References}

1. Yap CK, Mohd Ruszaidi S, Tan SG (2009) A preliminary study on the heavy metal concentrations in the barnacle Balanus sp. collected from Penang Bridge and Sungai Semilang, Penang. Malays. Appl Biol 38(1): 65-70.

2. Anil AG, Wagh AB (1988) Accumulation of copper and zinc by Balanus Amphitrite in a tropical estuary. Mar Pollut Bull 19(4): 177-180.

3. Paez Osuna F, Bdjorquez Leyva H, Ruelas Inzunza J (1999) Regional variations of heavy metal concentrations in tissues of barnacles from the subtropical Pacific coast of Mexico. Environ Int 25(5): 647-654.

4. Rainbow PS, Smith BD (1992) Biomonitoring of Hong Kong coastal trace metals by barnacles, $1986-1989$. Proc. $4^{\text {th }}$ international marine biologi- cal workshop: The marine flora and fauna of Hong Kong and southern China. Hong Kong: Hong Kong University Press pp. 585-597.

5. Rainbow PS, Blackmore G (2001) Barnacles as bio monitors of trace metal availabilities in Hong Kong coastal waters: changes in space and time. Mar Environ Res 51(5): 441-463.

6. Blackmore G, Morton B, Huang ZG (1998) Heavy metals in Balanus Amphitrite and Tetraclita squamosa (Crustacea: Cirripedia) collected from the coastal waters of Xiamen, China. Mar Pollut Bull 36(1): 32-40.

7. Rainbow PS, Wolowicz M, Fialkowski W, Smith BD, Sokolowski A (2000) Biomonitoring of trace metals in the Gulf of Gdansk, using mussels (Mytilus trossulus) and barnacles (Balanus improvisus). Wat Res 34(6): 1823-1829.

8. Silva ETD, Michael R, David K (2009) The barnacle Balanus Amphitrite as a bio monitor for Cd: Radiolabeled experiments. Mar Environ Res 67: 117-182.

9. Takashi $O$ (2000) Marine molluscs in Japan. Tokai University, Japan. Tokai University Press, Japan.

10. Yap CK, Ismail A, Tan SG, H Omar (2002) Correlations between speciation of $\mathrm{Cd}, \mathrm{Cu}, \mathrm{Pb}$, and $\mathrm{Zn}$ in sediment and their concentrations in total soft tissue of green-lipped mussel Perna viridis from the west coast of Peninsular Malaysia. Environ Int 28(1-2): 117-126.

11. Badri MA, Aston SR (1983) Observation on heavy metal geochemical associations in polluted and non-polluted estuarine sediments. Environ Pollut Ser B 6: 181-193.

12. Calcagno JA, Gappa JL, Tablado A (1998) Population dynamics of the barnacle Balanus amphitrite in an intertidal area affected by sewage pollution. J Crustacean Biol 18(1):128-137.

13. Rainbow PS (1987) Heavy metals in barnacles. In: Barnacle biology. Southward AJ, Balkema AA (eds) Rotterdam. pp.405-417.

14. Rainbow PS (1998) Phylogeny of trace metal accumulation in crustacean. In: Metal metabolism in aquatic environment. Langston WJ, Bebianno M (eds). London, Chapman and Hall. pp. 285-319.

15. Rainbow PS (1990) Heavy metal levels in marine invertebrates. In Heavy Metals in the Marine Environment. Furness RW, Rainbow (eds) PS pp.67-79.

16. Rainbow PS, White SL (Eds.), Comparative strategies of heavy metal accumulation by crustaceans, zinc, copper and cadmium in a decapod, an amphipod and a barnacle. Hydrobiologia CRC Press, Boca Raton, Florida 174: $245-262$

17. Rainbow PS (1995) Biomonitoring of heavy metal availability in the marine environment. Mar Pollut Bull 31:183-192.

18. Rainbow PS (1985) Accumulation of $\mathrm{Zn}, \mathrm{Cu}$ and $\mathrm{Cd}$ by crabs and barnacles. Estuar Coast Shelf Sci 21(5): 669-686.

19. Rainbow PS (1995) Biomonitoring of heavy metal availability in the marine environment Mar Pollut Bull 31: 183-192. 